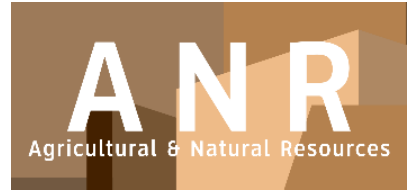

PAPER - OPEN ACCESS

Potensi Berbagai Tanaman Sebagai Moluskisida Nabati untuk Mengendalikan Keong Mas Pomacea canaliculata Lamarck (Mollusca: Ampullariidae) pada Tanaman Padi di Rumah Kaca

$\begin{array}{ll}\text { Author } & : \text { Parlaungan Harahap } \\ \text { DOI } & : 10.32734 / \text { anr.v1i1.103 } \\ \text { Electronic ISSN } & : 2654-7023 \\ \text { Print ISSN } & : 2654-7015\end{array}$

Volume 1 Issue 2 - 2018 TALENTA Conference Series: Agricultural \& Natural Resources (ANR)

This work is licensed under a Creative Commons Attribution-NoDerivatives 4.0 International License.

Published under licence by TALENTA Publisher, Universitas Sumatera Utara
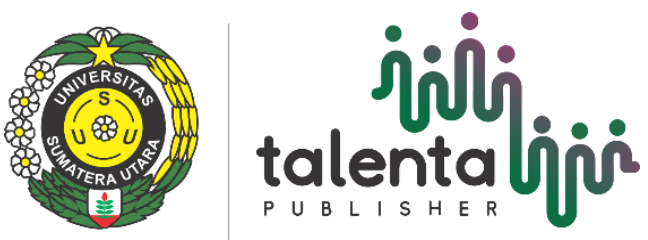


\title{
Potensi Berbagai Tanaman Sebagai Moluskisida Nabati untuk Mengendalikan Keong Mas Pomacea canaliculata Lamarck (Mollusca: Ampullariidae) pada Tanaman Padi di Rumah Kaca
}

\author{
Parlaungan Harahap ${ }^{\mathrm{a}}$, Syahrial Oemry ${ }^{\mathrm{a}}$, Lisnawita ${ }^{\mathrm{a}^{*}}$ \\ Fakultas Pertanian, Universitas Sumatera Utara, Medan 20155, Indonesia
}

itamuis@yahoo.com

\begin{abstract}
Abstrak
Keong mas (Pomacea canaliculata Lamarck) merupakan salah satu hama penting pada tanaman padi yang sampai saat ini belum dapat dikendalikan dengan baik. Pengendalian dengan moluskisida kimia meninggalkan residu pada lingkungan. Oleh karena itu perlu dicari alternatif pengendalian yang ramah lingkungan seperti pengendalian biologi. Penelitian ini bertujuan untuk mendapatkan tanaman yang berpotensi sebagai moluskisida nabati yang dapat digunakan untuk mengendalikan keong mas pada tanaman padi di rumah kaca. Penelitian ini dilaksanakan pada bulan April sampai Juni 2016 di Rumah Kaca Fakultas Pertanian Universitas Sumatera Utara Medan. Metode yang digunakan adalah rancangan acak lengkap non faktorial dengan 6 perlakuan dan 4 ulangan yaitu keong mas (kontrol), serbuk pinang, serbuk tembakau, serbuk sirsak, serbuk mimba, dan moluskisida fentin asetat $60 \%$. Hasil penelitian menunjukkan serbuk pinang dan serbuk tembakau efektif mengendalikan keong mas dengan persentase mortalitas 100\% pada 3 sampai 4 hari setelah aplikasi dan mampu mencegah kerusakan rumpun tanaman padi. Kedua tanaman ini berpotensi sebagai moluskisida nabati untuk mengendalikan keong mas.
\end{abstract}

Kata Kunci: Pomacea canaliculata Lamarck; padi; molukisida nabati

\section{Pendahuluan}

Tanaman padi (Oryza sativa L) merupakan salah satu komoditas tanamn pangan yang harus terpenuhi kecukupannya untuk menunjang kelangsungan hidup sebahagian besar penduduk Indonesia. Pada tahun 2014 terjadi penurunan produksi sebesar $0.94 \%$ dari produksi tahun 2013 [4]. Hal ini dipengaruhi oleh serangan hama diantaranya adalah keong mas Pomacea canaliculata L. Kerusakan karena serangan keong mas terjadi ketika tanaman masih muda. Akibatnya petani harus menyulam atau menanam ulang pada daerah dengan populasi keong yang tinggi sehingga biaya produksi meningkat [9]. Tidak ada varietas padi yang tahan terhadap serangan hama keong mas [6]. Untuk mengatasi masalah tersebut maka diperlukan cara pengendalian yang bijak.

Penggunaaan bahan kimia atau moluskisida sintetis dapat menimbulkan efek samping, seperti resistensi dan resurjensi hama dan pencemaran lingkungan. Oleh karena itu, perlu dicari teknologi yang dapat menekan perkembangan hama yang ramah lingkungan seperti penggunaan pestisida nabati. Pestisida nabati adalah pestisida yang bahan dasarnya bersumber dari tumbuh-tumbuhan, seperti akar, daun, batang atau buahnya. Tanaman-tanaman tersebut di antaranya adalah pinang, tembakau, sirsak, dan mimba [3]. 
Beberapa penelitian telah dilaporkan penggunaan pinang, tembakau, sirsak dan mimba sebagai pestisida nabati. Laoh [7] melaporkan aplikasi tepung biji pinang telah mampu menyebabkan mortalitas hama keong emas sampai $87,49 \%$. Meikawati [8] menunjukkan banyaknya ulat $S$. litura yang mati pada kosentrasi nikotin 1,00\% yaitu 7,91 dari 12 ulat yang diujikan. Selanjutnya Tambunan (2010) menunjukkan serbuk biji sirsak 5gr/200gr kacang hijau menyebabkan mortalitas C. chinensis sebesar $100 \%$. Ardiansyah [1] melaporkan ekstrak daun mimba bersifat toksik pada anakan siput murbei dengan tingkat kematian anakan mencapai 98,35\% pada konsentrasi 27,5\%. Berdasarkan uraian tersebut, peneliti tertarik untuk meneliti beberapa pestisida nabati yang dapat digunakan untuk mengendalikan keong mas pada tanaman padi di rumah kaca.

\section{Bahan dan Metode}

Penelitian ini dilaksanakan di Laboratorium Penyakit Tumbuhan dan rumah kaca Fakultas Pertanian Universitas Sumatera Utara, Medan dengan ketinggian tempat $\pm 25 \mathrm{~m}$ dpl pada bulan April sampai Juni 2016. Bahan yang digunakan adalah buah pinang, daun tembakau, daun mimba, daun sirsak, pupuk NPK, benih padi, tanah sawah, dan lain-lain. Adapun alat yang digunakan adalah timbangan, beaker glass, blender, sungkup, dan alat pendukung lainnya.

Penelitian ini menggunakan rancangan acak lengkap (RAL) non faktorial dengan perlakuan sebagai berikut : P0 : keong mas (kontrol); P1 : ekstrak pinang 10 gr; P2 : ekstrak tembakau 10 gr; P3 : serbuk sirsak 10 gr; P4 : serbuk mimba 10 gr; P5 : Moluskisida kimia 0.0035 gr (fentin asetat $60 \%$ ).

\section{Pelaksanaan Penelitian}

\subsection{Penyemaian Benih}

Tanah untuk media semai dibersihkan, dimasukkan ke dalam bak kecambah diratakan dengan ketinggian $10 \mathrm{~cm}$, sebelum penyemaian, benih direndam terlebih dahulu selama 48 jam kemudian ditabur di atas tanah secara merata. Benih yang digunakan adalah benih padi Ciherang. Tanah yang digunakan adalah tanah sawah yang diambil dari sawah Kampung Susuk Kecamatan Medan Selayang, yang kemudian dimasukkan kedalam ember berdiameter \pm 25 cm dengan ketinggian $\pm 27 \mathrm{~cm}$.

\subsection{Penanaman Bibit}

Bibit yang ditanam adalah bibit yang sudah berumur 25-30 hari, berdaun 5-7 helai, tingginya $\pm 25 \mathrm{~cm}$, batangnya besar dan kuat serta bebas dari serangan hama dan penyakit. Pada tiap ember di tanam 4 rumpun padi. Setiap rumpun terdapat 5 batang bibit dan ditanam tegak lurus dengan kedalaman $\pm 3 \mathrm{~cm}$. Jarak antara satu rumpun dengan rumpun yang lain sekitar $12 \mathrm{~cm}$. Dilakuakan penyungkupan untuk menghindari masuknya hama bukan sasaran dan keluarnya hama utama.

\subsection{Pembuatan Moluskisida Nabati}

Pinang yang di gunakan bagian inti endosperm pinang dicuci dengan air dan dijemur selama 1 minggu untuk mengurangi kadar air kemudian diblender hingga menjadi serbuk kemudian disaring dengan ayakan tepung.

Daun tembakau yang di gunakan adalah daun yang tidak terlalu tua juga tidak terlalu muda dicuci dengan air dan dijemur selama 1 minggu untuk mengurangi kadar air kemudian diblender hingga menjadi serbuk dan disaring dengan ayakan tepung. Daun sirsak yang di gunakan adalah daun yang tidak terlalu tua,bebas hama penyakit, dicuci dengan air dan dijemur selama 1 minggu untuk mengurangi kadar air, dilakukan pemisahan tulang daun kemudian diblender hingga menjadi serbuk dan disaring.

Daun mimba yang di gunakan adalah daun yang tidak terlalu tua juga, dicuci dengan air dan dijemur selama 1 minggu untuk mengurangi kadar air kemudian diblender hingga menjadi serbuk dan disaring dengan ayakan tepung. 


\subsection{Inokulasi Keong Mas}

Keong mas dikumpulkan dari lapangan kemudian diinkubasi selama satu minggu dan diberi makan daun padi 2 kali sehari. Keong mas yang digunakan adalah keong mas fase dewasa yang sehat berukuran 2 sampai $3 \mathrm{~cm}$ dan diinfestasikan ke tanaman 1 minggu setelah tanam pada sore hari sebanyak 4 ekor. Keong mas tersebut diletakkan di pinggir mulut ember.

\subsection{Pemeliharaan Tanaman}

Pemupukan tanaman dilakukan pada saat tanaman berumur 2 minggu setelah tanam (MST). Pupuk yang digunakan adalah pupuk NPK. Penyulaman dilakukan pada pagi/sore hari bila ada tanaman yang mati atau rusak sebelum diaplikasikan keong mas.

\subsection{Peubah Amatan}

\subsubsection{Mortalitsa Hama}

Pengambilan data persentase mortalitas keong mas dilakukan pada 1 hari setelah aplikasi (hsa) hingga17 hsa. Dihitung dengan menggunakan rumus :

Dimana :

$$
P=\frac{a}{a+b} 100 \%
$$

$\mathrm{P}=$ Persentasi mortalitas hama

$\mathrm{a}=$ Jumlah keong yang mati

$\mathrm{b}=$ Jumlah keong yang hidup

\subsubsection{Persentase rumpun terserang}

Pengamatan dilakukan dengan cara menghitung jumlah bibit yang berhasil tumbuh dibagi jumlah bibit yang ditanam dan dihitung pada saat tanaman padi berumur 2 bulan. Dihitung dengan menggunakan rumus :

Dimana :

$$
P=\frac{a-b}{a} \times 100 \%
$$

$\mathrm{P}=$ Persentasi serangan hama

$\mathrm{a}=$ Jumlah bibit awal

$\mathrm{b}=$ Jumlah bibit tersisa

\subsubsection{Waktu Kematian}

Waktu kematian adalah rentan waktu yang diperlukan oleh masing masing perlakuan sampai menimbulkan kematian pada keong mas. Waktu kematian bervariasi, oleh karena itu pengamatan dilakukan mulai dari 1, 2, 3, 4, 5, 6,7 hari dan seterusnya setelah aplikasi.

\section{Hasil dan Pembahasan}

\subsection{Mortalitas Hama}

Dari hasil analisis sidik ragam menunjukkan bahwa pemberian serbuk nabati memberikan pengaruh nyata terhadap mortalitas keong mas untuk semua perlakuan. Hal ini dapat dilihat pada Tabel 1. 
Tabel 1. Persentase mortalitas keong mas P. canaliculata untuk setiap perlakuan.

\begin{tabular}{|c|c|c|c|c|c|c|c|c|c|c|}
\hline \multirow{2}{*}{$\begin{array}{l}\text { Perla } \\
\text { kuan }\end{array}$} & \multicolumn{10}{|c|}{ Waktu Pengamatan (Hari Setelah Aplikasi) } \\
\hline & $1 \mathrm{hsa}$ & 2 hsa & $3 \mathrm{hsa}$ & $4 \mathrm{hsa}$ & 5 hsa & $6 \mathrm{hsa}$ & $\begin{array}{l}\text { 7-14 } \\
\text { hsa }\end{array}$ & $15 \mathrm{hsa}$ & $16 \mathrm{hsa}$ & $17 \mathrm{hsa}$ \\
\hline $\mathrm{P} 0$ & $0.00 \mathrm{~b}$ & $0.00 \mathrm{c}$ & $0.00 \mathrm{c}$ & $0.00 \mathrm{c}$ & $0.00 \mathrm{c}$ & $0.00 \mathrm{~b}$ & $0.00 \mathrm{~b}$ & $0.00 \mathrm{c}$ & $0.00 \mathrm{c}$ & $0.00 \mathrm{c}$ \\
\hline \multirow[t]{2}{*}{ P1 } & 50.00 & 93.75 & 100.00 & 100.00 & 100.00 & 100.00 & 100.00 & 100.00 & 100.00 & 100.00 \\
\hline & a & $\mathrm{a}$ & $\mathrm{a}$ & $\mathrm{a}$ & $\mathrm{a}$ & $\mathrm{a}$ & $\mathrm{a}$ & $\mathrm{a}$ & $\mathrm{a}$ & $\mathrm{a}$ \\
\hline \multirow[t]{2}{*}{$\mathrm{P} 2$} & 56.25 & 93.75 & 100.00 & 100.00 & 100.00 & 100.00 & 100.00 & 100.00 & 100.00 & 100.00 \\
\hline & a & $\mathrm{a}$ & $\mathrm{a}$ & $\mathrm{a}$ & $\mathrm{a}$ & $\mathrm{a}$ & $\mathrm{a}$ & $\mathrm{a}$ & $\mathrm{a}$ & $\mathrm{a}$ \\
\hline P3 & $0.00 \mathrm{~b}$ & $0.00 \mathrm{c}$ & $0.00 \mathrm{c}$ & $0.00 \mathrm{c}$ & $0.00 \mathrm{c}$ & $6.25 b$ & $6.25 b$ & $12.50 \mathrm{~b}$ & $25.00 \mathrm{~b}$ & $31.25 \mathrm{~b}$ \\
\hline \multirow[t]{2}{*}{$\mathrm{P} 4$} & 18.75 & 62.50 & 75.00 & $87.50 \mathrm{a}$ & 93.75 & 100.00 & 100.00 & 100.00 & 100.00 & 100.00 \\
\hline & $\mathrm{b}$ & $\mathrm{b}$ & $\mathrm{b}$ & $\mathrm{b}$ & a & a & a & a & a & a \\
\hline \multirow[t]{2}{*}{ P5 } & 18.75 & 50.00 & 68.75 & 75.00 & 81.25 & 93.75 & 100.00 & 100.00 & 100.00 & 100.00 \\
\hline & $\mathrm{b}$ & $\mathrm{b}$ & $\mathrm{b}$ & $\mathrm{b}$ & $\mathrm{b}$ & $\mathrm{a}$ & $\mathrm{a}$ & $\mathrm{a}$ & $\mathrm{a}$ & $\mathrm{a}$ \\
\hline
\end{tabular}

Keterangan: Angka-angka yang diikuti oleh notasi huruf yang sama pada kolom yang sama tidak berbeda nyata menurut uji Duncan pada taraf 5\%. P0 (Kontrol); P1 (10 gr serbuk biji pinang); P2 (10 gr sebuk daun tembakau); P3 (10 gr serbuk daun mimba); P4 (10 gr serbuk daun sirsak); dan P5 (0.0035 gr moluskisida kimia fentin asetat 60\%).

Pada Tabel 1 dapat diketahui bahwa pada perlakuan P0 tidak terjadi kematian keong mas dari 1 hsa sampai 17 hsa. Pada pengamatan 1 hsa, perlakuan P1 (10 gr serbuk biji pinang) berbeda nyata dengan kontrol. Pada pengamatan 3 hsa perlakuan P1 menunjukkan persentase mortalitas keong mas 100\%, sehingga perlakuan P1 merupakan perlakuan yang paling efektif dari seluruh perlakuan. Hal ini dikarenakan serbuk nabati biji pinang mengandung senyawa yang toksisitasnya cukup tinggi terhadap keong mas. Biji pinang mengandung senyawa alkaloid yaitu sebuah ester metal-tetrahidrometil-nikotinat yang berwujud minyak basa keras bersifat toksik menyebabkan kelumpuhan dan terhentinya pernafasan keong mas [5].

Dari Tabel 1 menunjukan bahwa pada perlakuan P2 serbuk tembakau pada hari ke 4 sudah menujukkan persentase mortalitas keong mas $100 \%$ tidak berbeda nyata dengan P1 tetapi berbeda sangat nyata dengan P3, P4, P5 dan kontrol. Hal ini dikarenakan daun tembakau mengandung zat nikotin. Nikotin akan mempengaruhi ganglia dari sistem saraf pusat hama. Pada kadar yang rendah, nikotin akan menyebabkan konduksi transinaptis, sedang pada kadar yang tinggi akan menyebabkan penghambatan konduksi (blocking conduction) karena terjadinya peresapan ion nikotin ke dalam benang saraf yang kemudian akan mematikan hama [13].

Dari hasil pengamatan pada 1 hsa sampai 5 hsa perlakuan P3 serbuk nabati daun mimba belum menimbulkan pengaruh yang mematikan terhadap keong mas. Kematian keong mas baru tampak pada 6 hsa dengan persentase mortalitas yaitu $6,65 \%$. Serbuk daun mimba mengandung senyawa limonoid yang telah diindentifikasi diantaranya adalah azadirachtin, meliantriol, salanin, kandungan ini dapat dengan cepat terserap melalui permukaan kulit, melumpuhkan urat syaraf dan menyebabkan kematian. Selain itu juga berpengaruh dalam proses pencernaan makanan, menghambat kontraksi usus, sehingga proses pencernaan makanan tidak dapat berlangsung [1].

Dari Tabel 1 menunjukan bahwa pada perlakuan P1 lebih efektif di bandingkan P5 (0.0035 gr moluskisida kimia fentin asetat 60\%) hal ini dikarenakan pada 3 hsa persentase mortalitas keong mas sebesar 100\% dan P5 sebesar $68.75 \%$. Penggunaan moluskisida nabati sangat baik untuk diaplikasikan. Moluskisida nabati hanya menyerang hama dan tidak menimbulkan masalah terhadap musuh musuh alami seperti predator dan tidak merusak ekosistem. Berbeda dengan penggunaan pestisida kimia yang dapat membunuh seluruh serangga baik hama maupun musuh alami. Hal ini sesuai dengan pernyataan syakir (2011) bahwa Pestisida nabati bersifat mudah terurai (biodegradable) di alam, sehingga tak mencemari lingkungan dan relatif aman bagi manusia, tidak membunuh musuh alami dan ternak peliharaan, karena residu (sisa-sisa zat) mudah hilang. 


\subsection{Persentase Rumpun Terserang}

Dari hasil sidik ragamnya menunjukkan pada perlakuan pemberin serbuk nabati berpengaruh nyata terhadap persentase rumpun terserang. Hal ini dapat dilihat pada Tabel 2.

Table 2. Persentase rumpun terserang untuk setiap perlakuan (\%).

\begin{tabular}{ll}
\hline Perlakuan & Persentase Rumpun Terserang (\%) \\
\hline P0 & $100,00 \mathrm{a}$ \\
P1 & $0,00 \mathrm{c}$ \\
P2 & $0,00 \mathrm{c}$ \\
P3 & $87,50 \mathrm{~b}$ \\
P4 & $0,00 \mathrm{c}$ \\
P5 & $0,00 \mathrm{c}$ \\
\hline
\end{tabular}

Keterangan : Angka-angka yang diikuti oleh notasi huruf yang sama pada kolom yang sama tidak berbeda nyata menurut uji Duncan pada taraf $5 \%$.

Dari Tabel 2 menunjukkan bahwa pada perlakuan P1, P2, P4, dan P5 persentase rumpun terserang berbeda nyata dengan perlakuan P0 dan P3. Pada perlakuan P1, P2, P4, dan P5 persentase rumpun terserang 0\% dikarenakan serbuk nabati dapat mengendalikan hama keong mas dengan tingkat mortalitas yang tinggi sedangkan pada perlakuan P0 dan P3 persentase rumpun terserang 100\% dan 87,50\% (Gambar 1). Hal ini kembali dibuktikan dengan tingkat populasi keong mas yang sangat berpengaruh terhadap kerusakan tanaman padi. Populasi hama keong mas yang rendah atau dikendalikan, maka tanaman padi tidak mengalami kerusakan yang parah (Susetyo et al., 2008).

Dari Tabel 2 menunjukkan bahwa pada perlakuan P3 persentase rumpun terserang mencapai 87,50\% hal ini disebabkan mortalitas yang rendah menjadikan keong mas berpeluang untuk menyerang rumpun padi. Selanjutnya dapat diartikan bahwa serbuk mimba kurang efektif dalam pengendalian keong mas. Ada beberapa faktor yang menyebabkan ketidak efektifan pestisida nabati yaitu Pertama, tingkat konsentrasi yang diberikan. Kedua, faktor lingkungan alam, biopestisida merupakan pestisida nabati yang sangat dipengaruhi oleh keadaan lingkungan sekitar. Kelemahan dari biopestisida antara lain : 1) daya kerja relatif lambat, 2) tidak membunuh jasad secara langsung, 3) tidak tahan simpan dalam waktu yang lama. 4) jika terkena hujan, kepekatan zat racun biopestisida akan memudar (Arsyadana, 2014). 

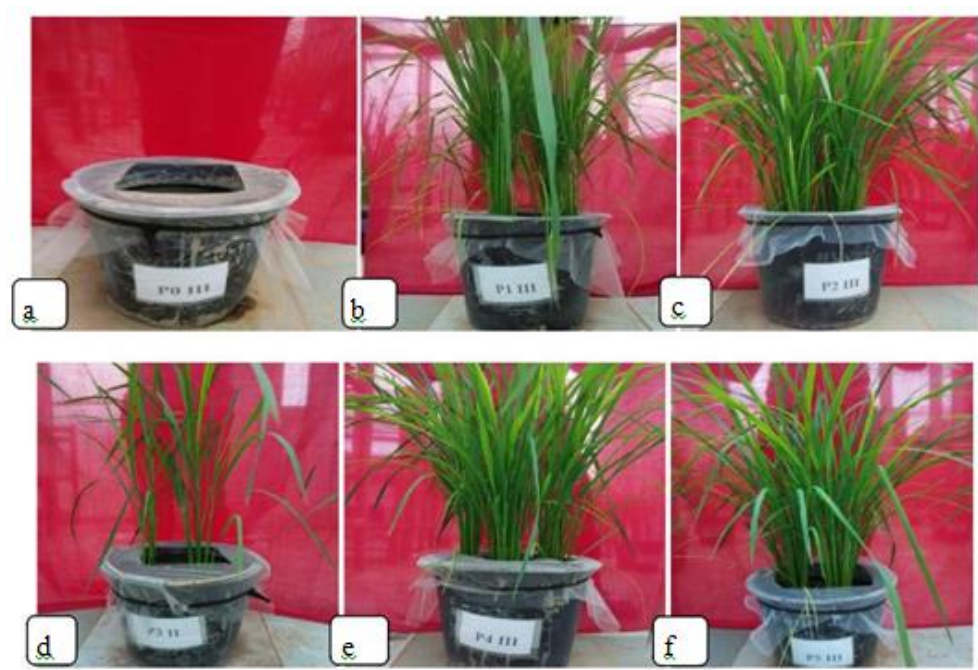

Gambar.1. Persentase rumpun terserang (a) P0 (Kontrol); (b) P1 (10 gr serbuk biji pinang); (c) P2 (10 gr sebuk daun Tembakau); (d) P3 (10 gr serbuk daun mimba); (e) P4 (10 gr serbuk daun sirsak); dan (f) P5 (0.0035 gr moluskisida kimia fentin asetat $60 \%$.

\subsection{Waktu Kematian Keong Mas}

Hasil pengamatan waktu kematian keong mas untuk setiap perlakuan dapat dilihat pada Tabel 4 . Tabel 4 menunjukkan bahwa waktu kematian keong mas tercepat terdapat pada perlakuan P1, P2, P4, dan P5 pada 1 hsa sedangkan waktu kematian keong mas paling lama terdapat pada perlakuan P3 pada 6 hsa . Perlakuan P3 berbeda 5 hari dengan perlakuan lainnya, ini dikarenakan cangkang keong yang keras dan sering menutup diri sehingga racun mimba tidak sampai ke permukaan kulit keong mas. Racun yang terkandung dalam ekstrak daun mimba dapat dengan cepat terserap melalui permukaan kulit, melumpuhkan urat syaraf dan menyebabkan kematian dengan segera [1] dan dikarenakan kurang banyaknya konsentrasi yang diberikan. Semakin tinggi konsentrasi yang digunakan maka semakin cepat hama mati. Hal ini sesuai dengan Laoh [7] yang menyatakan bahwa pemberian konsentrasi yang semakin tinggi, maka semakin cepat serangga mati, dikarenakan semakin banyak zat aktif yang masuk/terkena pada hama.

Tabel 4. Pengaruh serbuk nabati terhadap waktu kematian keong mas untuk setiap perlakuan.

\begin{tabular}{ll}
\hline Perlakuan & Waktu Kematian \\
\hline $\mathrm{P}$ & 0 \\
$\mathrm{P}$ & 1 \\
$\mathrm{P}$ & 1 \\
$\mathrm{P}$ & 6 \\
$\mathrm{P}$ & 1 \\
$\mathrm{P}$ & 1 \\
\hline
\end{tabular}

Keterangan : P0 (Kontrol); P1 (10 gr serbuk biji pinang); P2 (10 gr sebuk daun Tembakau); P3 (10 gr serbuk daun mimba); P4 (10 gr serbuk daun sirsak); dan P5 (0.0035 gr moluskisida kimia fentin asetat $60 \%)$. 
Gejala keracunan yang tampak pada keong mas dalam keadaan hidup yakni frekuensi buka-tutup operkulum meningkat, warna permukaan otot memucat, dan pergerakan serta perilaku makan keong mas yang menurun. Sedangkan gejala klinis yang terjadi pada keong mas setelah mengalami kematian yakni warna permukaan otot memucat, otot melunak dan keluar dari cangkang berlendir, serta operkulum terbuka (Gambar 2). Gejala tersebut merupakan respon keong mas saat terdapat zat-zat lain yang menghambat proses metabolisme sel dalam tubuh keong.
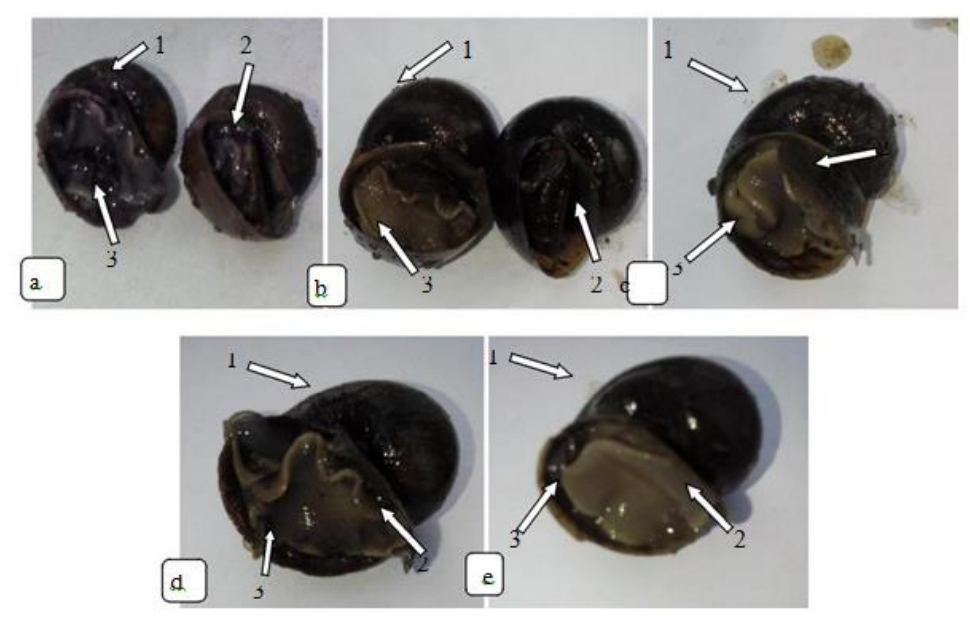

Gambar. 2. Kematian keong mas (a) P1 (10 gr serbuk biji pinang); (b) P2 (10 gr sebuk daun Tembakau); (c) P3 (10 gr serbuk daun mimba); (d) P4 (10 gr serbuk daun sirsak); dan (e) P5 (0.0035 gr moluskisida kimia fentin asetat 60\%) (1) cangkang keong mas, (2) operkulum, (3) otot keong mas.

\section{Kesimpulan}

Semua perlakuan moluskisida nabati yang diuji dapat mengendalikan keong mas. Serbuk pinang dan serbuk tembakau berpotensi sebagai moluskisida nabati yang dapat digunakan untuk mengendalikan keong mas dengan persentase mortalitas $100 \%$ pada 3 sampai 4 hari setelah aplikasi dan mampu mencegah kerusakan rumpun tanaman padi.

\section{Referensi}

[1] Ardiansyah., Wiryanto. dan Edwi, M. (2002). Toksisitas Ekstrak Daun Mimba (Azadirachta indica A. Juss) pada Anakan Siput Murbei (Pomacea canaliculata L.). Bio Smart. 4 (1), 29-34.

[2] Arsyadana. (2014). Efektivitas Biopestisida Biji Mahkota Dewa (Phaleria macrocarpa) dengan Lama Fermentasi yang Berbeda untuk Mengendalikan Hama Keong Mas (Pomacea canaliculata) pada Tanaman Padi (Oryza sativa L). Jurnal Publikasi. Fakultas Keguruan dan Ilmu Pendidikan Universitas Muhammadiyah Surakarta.

[3] Asmaliyah., Wati, E.E.H., Utari, S., Mulyani, K., Yudhistira. dan Sari, F.W. (2010). Pengenalan Tumbuhan Penghasil Pestisida Nabati dan Pemanfaatannya Secara Tradisional. Badan Penelitian dan Pengembangan Kehutanan. Pusat Penelitian dan Pengembangan Produktivitas Hutan..

[4] Badan Pusat Statistik. (2014). Produksi padi, jagung dan kedelai. https://www.bps.go.id/linkTableDinamis/view/id/865. Diakses pada tanggal 30 Februari 2016.

[5] Gassa A. (2011). Pengaruh Buah Pinang (Areca catechu) terhadap Mortalitas Keong Mas (Pomacea canaliculata) pada Berbagai Stadia. Universitas Hasanudin. Makassar. J. Fitomedika. 7 (3), 171-174.

[6] Hutasoit, R.T. (2012). Uji Beberapa Varietas Tanaman Padi (Oryza sativa. L.) terhadap Hama Keong Mas (Pomaceae canaliculata Lamarck) (Mollusca ; Ampullariidae). Skripsi. Fakultas Pertanian. Universitas Andalas. Padang.

[7] Laoh, H., Rustam, R. dan Permana, R. (2013). Pemberian Beberapa Dosis Tepung Biji Pinang (Areca catechu L.) Lokal Riau untuk Mengendalikan Hama Keong Emas (Pomacea canaliculata L.) pada Tanaman Padi. 1 (2), 1-7. 
[8] Meikawati, W., Salawati, T. dan Nurulita, U. (2013). Pemanfaatan Ekstrak Tanaman Tembakau (Nicotianae Tobacum L) Sebagai Pestisida untuk Pengendalian Hama Ulat Grayak pada Tanaman Cabai. Prosiding Seminar Nasional. Fakultas Kesehatan Masyarakat Universitas Muhammadiyah Semarang.

[9] Roja, A. (2009). Pengendalian Hama dan Penyakit Secara Terpadu (PHT) pada Padi Sawah. Balai Pengkajian Teknologi Pertanian Sumatera Barat.

[10] Susetyo, T., Ruswandi. dan Etty, P. (2008). Tekhnologi Pengendalian Organisme Pengganggu Tanaman (OPT) Ramah Lingkungan. Direktorat Perlindungan Pangan. Jakarta.

[11] Syakir, M. (2011). Status Penelitian Pestisida Nabati Pusat Penelitian dan Pengembangan Tanaman Perkebunan. Badan Litbang Pertanian. Bogor.

[12] Tambunan, C.B.S.N. (2010). Penggunaan Beberapa Serbuk Biji Tanaman untuk Mengendalikan Callosobruchus chinensis L. (Coleoptera: Bruchidae) Pada Kacang Hijau (Vigna radiata L.) di Laboratorium. Skripsi. Fakultas Pertanian. Universitas Sumatera Utara.

[13] Tuti, H.K. (2015). Efektivitas Limbah Tembakau untuk Pengendali Wereng Batang Coklat dan Pengaruhnya terhadap Kumbang Tomcat. Thesis. Program Studi Magister Entomologi Program Pascasarjana Institut Pertanian Bogor. Bogor. 